\title{
Effect of composting on characterization and leaching of copper, manganese, and zinc from swine manure
}

\author{
Jenn-Hung $\mathrm{Hsu}^{\mathrm{a}, *}$, Shang-Lien Lo ${ }^{\mathrm{b}}$ \\ ${ }^{a}$ Environmental Education Center, National Taitung Normal College, 684, Sec. 1, Chung-Hwa Road, Taitung, 950, Taiwan, ROC \\ ${ }^{\mathrm{b}}$ Graduate Institute of Environmental Engineering, National Taiwan University, 71, Chou-Shan Road, Taipei, 106, Taiwan, ROC
}

Received 8 April 1999; accepted 23 September 2000

"Capsule": The three metals differed in potential for leaching and bioavailability, with Zn being the most available.

\begin{abstract}
This research was conducted to study the influence of composting on the concentrations, water solubility, and phase association of $\mathrm{Cu}, \mathrm{Mn}$, and $\mathrm{Zn}$ from swine (Sus domesticus) feces. Composting of separated swine manure was performed in two piles for 122 days. The metal concentrations increased rapidly during the first 49 days and leveled off thereafter. All metal concentrations increased approximately 2.7 -fold in the final compost due to decomposition of organic matter. A sequential extraction protocol was used to evaluate the humification process and partition metals into water-soluble, exchangeable, organically complexed, organically bound, solid particulate, and residual fractions. Temporal changes in the water-soluble fractions of $\mathrm{Cu}, \mathrm{Mn}$, and $\mathrm{Zn}$ were reflected by water-soluble organic $\mathrm{C}$ concentrations, which rapidly increased to a maximum at Day 18 and declined thereafter. An increase in the humic acid/fulvic acid ratio in $\mathrm{Na}_{4} \mathrm{P}_{2} \mathrm{O}_{7}$ or $\mathrm{NaOH}$ extracts at various stages of composting represented the humification process. During composting, the major portions of $\mathrm{Cu}, \mathrm{Mn}$, and $\mathrm{Zn}$ were in the organically-bound, solid particulate, and organically complexed fractions, respectively. Metal distributions in different chemical fractions were generally independent of composting age and, thus, independent of respective total metal concentrations in the composts. (C) 2001 Elsevier Science Ltd. All rights reserved.
\end{abstract}

Keywords: Swine manure; Composting; Heavy metal; Organic carbon; Sequential extraction; Fractionation

\section{Introduction}

Intensive livestock production generates large amounts of manure that are applied to limited land area in proximity to the manure source. Continuous heavy manuring may pose environmental problems, such as odor, pollution of ground and surface waters due to leaching and run-off of organics and nutrients, and soil accumulation of heavy metals (Wadman et al., 1987). In Taiwan, swine house manure is normally cleaned daily with groundwater down a sump where the solid fraction is separated form slurry through a mechanical sieve. Composting of solid fraction or separated swine manure (SSM) prior to land application may provide a better alternative for manure management.

The composting of organic wastes is mainly a biological decomposition process of organic materials, resulting in a net loss of total organic matter $(\mathrm{OM})$ and a

\footnotetext{
* Corresponding author.

E-mail address: barry@cc.ntttc.edu.tw (J.-H. Hsu).
}

concentration of inorganic constituents (He et al., 1995). The main products of the composting process are fully mineralized materials such as $\mathrm{CO}_{2}, \mathrm{H}_{2} \mathrm{O}$, mineral ions, stabilized OM (mostly humic substances), and ash. Composting reduces the volume and weight of the raw material resulting in a stable product that can be applied to soil as a valuable fertilizer and soil amendment.

Several researches have shown that swine manure may contain high concentrations of $\mathrm{Cu}, \mathrm{Mn}$, and $\mathrm{Zn}$ because of feed additives (Mullins et al., 1982; Miller et al., 1986; Payne et al., 1988; L'Herroux et al., 1997). Most of these trace elements are retained mainly in the solid phase after solid-liquid separation from slurry (Giusquiani et al., 1998). As such, successive application of $\mathrm{Cu}, \mathrm{Mn}$, and $\mathrm{Zn}$-rich SSM composts in agricultural soils may cause metals to accumulate to toxic levels (King et al., 1990).

In cases where the potential toxic metal concentrations of a compost are high, the leachability of metals associated with compost is of concern. Knowledge of the elemental concentration of a compost, however, does 
not allow for a prediction of its leachability and bioavailability. Studies have shown that the chemical form, rather than the total concentration, of an element is more important than total concentration in determining its availability for plant uptake or leachability into groundwater (Petruzzelli et al., 1989). Although several studies have assessed the leachability or bioavailability of elements in fresh swine manure, manure mixed with sawdust, and soils amended with swine manure (Mullins et al., 1982; Miller et al., 1986; Payne et al., 1988; L'Herroux et al., 1997; Tiquia et al., 1997), few similar studies have been conducted to evaluate the influence of composting on leaching of elements from SSM solids. Since decomposition of manure occurs through biological action and spontaneous chemical reactions, composting may influence the concentrations and chemical characterization of elements in SSM composts.

The objective of this work was to study the influence of composting on the concentrations, leachability, and chemical partitioning of $\mathrm{Cu}, \mathrm{Mn}$, and $\mathrm{Zn}$ in SSM solids. A sequential extraction protocol was used to evaluate the humification process and to determine the watersoluble fraction and the phase association of metals associated with SSM compost. These studies were designed to assess the potential leachability of $\mathrm{Cu}, \mathrm{Mn}$, and $\mathrm{Zn}$ and to identify factors that influence the leachability of these elements in SSM compost. This research may provide useful information for the successful utilization of SSM compost.

\section{Materials and methods}

\subsection{Composting of SSM}

The solid fraction or SSM obtained from separation of slurry was composted in two piles on an indoor concrete area at a swine farm where the swine were fed with a typical corn (Zea mays L.)/soybean [Glycine max (L.) Merr.] ration. The raw material was divided into two piles (about $1.5 \mathrm{~m}^{3}$ each) without forced aeration and composted for 122 days. The compost was turned, mixed, and sampled at $0,3,7,12,18,25,33,49,80$, and 122 days. Water was added immediately after the compost was turned to maintain a moisture content of 50 to $60 \%(\mathrm{w} / \mathrm{w})$. The samples $(41)$ were placed in partially closed polyethylene bags, transported to the laboratory, and stored at $5^{\circ} \mathrm{C}$. Smaller subsamples were air-dried and used for analyses. All measurements were conducted in triplicate for each composting pile.

\subsection{Chemical analyses}

Ash content was determined by heating $\left(400^{\circ} \mathrm{C}\right.$ for 8 h) in a furnace (He et al., 1995). Total C and $\mathrm{N}$ were analyzed using a $\mathrm{CHN}$ analyzer on composts ground to
$<0.25 \mathrm{~mm}$ (He et al., 1995). For total elemental analysis, samples were digested with concentrated $\mathrm{HNO}_{3}+\mathrm{HClO}_{4}$ (Jones and Case, 1990). The digest was centrifuged at $12,000 \times \boldsymbol{g}$ for $30 \mathrm{~min}$, and the supernatant was filtered through $0.45-\mu \mathrm{m}$ filter membranes for metals $(\mathrm{Cu}, \mathrm{Mn}$, and $\mathrm{Zn})$ analysis.

\subsection{Sequential extraction and fractionation}

The procedure of He et al. (1995), selected for this study, is designed to partition trace elements in composts into six operationally defined fractions: watersoluble, exchangeable, organically complexed, organically bound, solid particulate, and residue fractions (Fig. 1). Their method places more emphasis on the organic fraction (either $\mathrm{Na}_{4} \mathrm{P}_{2} \mathrm{O}_{7}$ or $\mathrm{NaOH}$ are effective in organic matter extraction) because of high organic matter content of SSM compost. Also, organics extracted by $\mathrm{Na}_{4} \mathrm{P}_{2} \mathrm{O}_{7}$ or $\mathrm{NaOH}$ are further separated into humic acid (HA) and fulvic acid (FA) fractions.

Twenty grams of each compost were weighed into a $250-\mathrm{ml}$ polycarbonate centrifuge tube and the following fractions obtained:

1. Water soluble. Compost sample was extracted with $200 \mathrm{ml}$ of deionized water by shaking for $24 \mathrm{~h}$.

2. Exchangeable. The residue from the water-soluble fraction was extracted with $200 \mathrm{~mL}$ of $1 \mathrm{M} \mathrm{KCl}$ for $24 \mathrm{~h}$.

3. Organically complexed. The residue from the exchangeable fraction was extracted with $200 \mathrm{ml}$ of $0.1 \mathrm{M} \mathrm{Na}_{4} \mathrm{P}_{2} \mathrm{O}_{7}$ for $24 \mathrm{~h}$. Add $5 \mathrm{~g} \mathrm{KCl}$ (to flocculate colloid particles) before centrifugation; the residue was washed with $200 \mathrm{ml}$ of deionized water by shaking $30 \mathrm{~min}$, adding $5 \mathrm{~g} \mathrm{KCl}$, centrifuging, and discarding the washing.

4. Organically bound. The residue from the organically complexed fraction was extracted with $200 \mathrm{ml}$ of $0.1 \mathrm{M} \mathrm{NaOH}$ for $24 \mathrm{~h}$. The washing was repeated.

5. Solid particulate. The residue from the organically bound fraction was extracted with $200 \mathrm{~mL}$ of $4 \mathrm{M}$ $\mathrm{HNO}_{3}$ for $24 \mathrm{~h}$.

6. Residual. The residue from the solid particulate fraction was digested with $\mathrm{HNO}_{3}$ and $\mathrm{HClO}_{4}$ acids.

After each successive extraction, separation was accomplished by centrifugation at $12,000 \times \boldsymbol{g}$ for $30 \mathrm{~min}$. The supernatants were removed with a pipette and filtered through $0.45-\mu \mathrm{m}$ filter membranes.

The $\mathrm{pH}$ of the water extracts were measured. An aliquot $(100 \mathrm{ml})$ of $\mathrm{Na}_{4} \mathrm{P}_{2} \mathrm{O}_{7}$ and $\mathrm{NaOH}$ extracts was acidified to $\mathrm{pH} 1$ with $3 \mathrm{M} \mathrm{H}_{2} \mathrm{SO}_{4}$ allowed to stand at room temperature for $24 \mathrm{~h}$, and centrifuged to obtain the FA fraction (HA fraction discarded). All extracts, residue digests, and FA fractions from $\mathrm{Na}_{4} \mathrm{P}_{2} \mathrm{O}_{7}$ and 


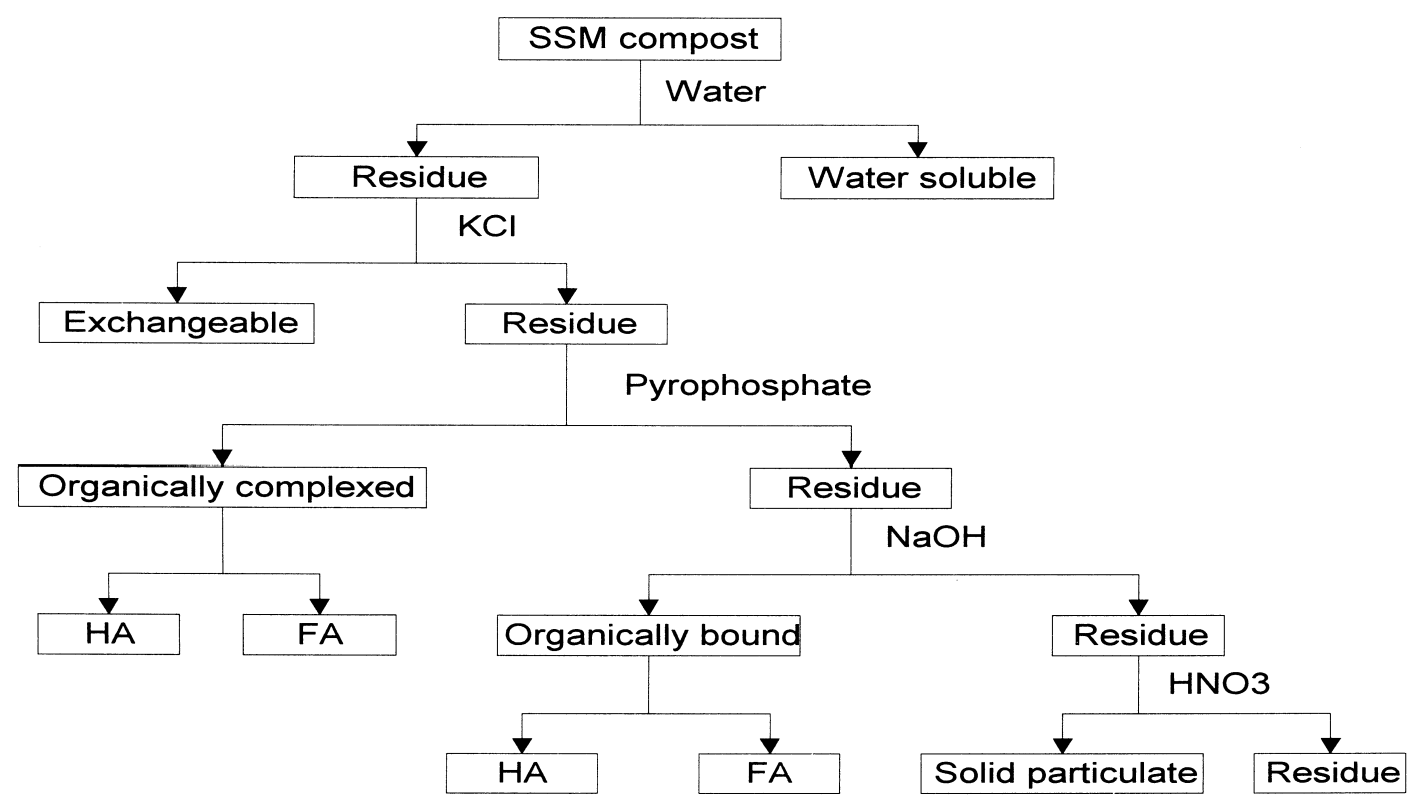

Fig. 1. Scheme for sequential extraction and fractionation of metals and organic $\mathrm{C}$ in composts.

$\mathrm{NaOH}$ extracts were stored at $5^{\circ} \mathrm{C}$ until analysis for $\mathrm{Cu}$, $\mathrm{Mn}, \mathrm{Zn}$, and organic $\mathrm{C}$ (residue digest excluded).

\subsection{Metal and organic $C$ analyses}

Metal analyses of digest and extract solution and FA fractions from $\mathrm{Na}_{4} \mathrm{P}_{2} \mathrm{O}_{7}$ and $\mathrm{NaOH}$ extracts were performed using an atomic absorption spectrophotometer. Organic $\mathrm{C}$ analyses of extract solutions and FA fractions from $\mathrm{Na}_{4} \mathrm{P}_{2} \mathrm{O}_{7}$ and $\mathrm{NaOH}$ extracts were conducted with a total organic carbon analyzer. Trace element and organic $\mathrm{C}$ contents in the HA fraction of $\mathrm{Na}_{4} \mathrm{P}_{2} \mathrm{O}_{7}$ and $\mathrm{NaOH}$ extracts were not analyzed directly but were calculated by the difference between total and FA values.

\subsection{Statistical analysis}

All results are presented as the average value of two composting piles, and the data for each pile is the average of three replicates. Correlation analysis was conducted with the Statistical Analysis System (SAS Institute, 1987) software.

\section{Results and discussion}

\subsection{Composting of SSM}

The change in the $\mathrm{C} / \mathrm{N}$ ratio and ash content reflects OM decomposition and stabilization during composting (Table 1). A rapid decrease in the $\mathrm{C} / \mathrm{N}$ ratio and an increase in ash content occurred during the first 18 days, followed by a slow change from Days 18 to 49 and a leveling off thereafter. The change in $\mathrm{C} / \mathrm{N}$ ratio and ash content followed trends in many composting systems (Inbar et al., 1993; Iannotti et al., 1994; Chefetz et al., 1996) and exhibited three phases: (1) a rapid decomposition phase lasting for the first 18 days, during which most of the OM decomposed; (2) Days 18 to 49; and (3) a stationary phase from Days 49 to the end of the experiment, during which the rate of OM decomposition was extremely low. The ash content of the final compost was $50 \%$ of the final mass, indicating this material was half organic and half inorganic matter.

\subsection{Condensation of metals}

Since no leaching and runoff took place during composting, the total concentrations of $\mathrm{Cu}, \mathrm{Mn}$, and $\mathrm{Zn}$ increased with composting time and the corresponding loss of $\mathrm{OM}$ (Fig. 2). The total concentrations of $\mathrm{Cu}$, $\mathrm{Mn}$, and $\mathrm{Zn}$ increased from 343, 121, and $577 \mathrm{mg} \mathrm{kg}^{-1}$, respectively, in raw material to 976,331 , and $1540 \mathrm{mg}$ $\mathrm{kg}^{-1}$, respectively, in mature compost, indicating $2.7-$ 2.8 times enrichment of these elements during the process. Compared with a $25-40 \%$ increase in $\mathrm{Cu}$ and $\mathrm{Zn}$ concentrations in spent pig litter (Tiquia et al., 1997), $15-36 \%$ increase in cattle manure (Inbar et al., 1993), 50 to $100 \%$ in municipal solid waste (MSW; Leita and De Nobili, 1991), and no significant increase in poultry manure composting systems (Ihnat and Fernandes, 1996), this result indicates that metal concentrations in SSM during composting was greatly enhanced. This result suggests that the types of composting and raw materials are of major importance to metal condensation 
Table 1

Chemical properties of separated swine manure at various stages of the composting process

\begin{tabular}{llllll}
\hline $\begin{array}{l}\text { Composting } \\
\text { time (days) }\end{array}$ & $\mathrm{Ash}\left(\mathrm{g} \mathrm{kg}^{-1}\right)$ & $\mathrm{C}\left(\mathrm{g} \mathrm{kg}^{-1)}\right.$ & $\mathrm{N}\left(\mathrm{g} \mathrm{kg}^{-1}\right)$ & $\mathrm{C} / \mathrm{N}$ & $\mathrm{pH}^{\mathrm{a}}$ \\
\hline 0 & & & & & \\
3 & 220 & 444 & 20.9 & 21.2 & 7.85 \\
7 & 252 & 436 & 21.3 & 20.5 & 7.59 \\
12 & 260 & 428 & 22.1 & 19.4 & 7.62 \\
18 & 274 & 416 & 23.1 & 18.0 & 7.83 \\
25 & 365 & 374 & 38.4 & 9.7 & 7.35 \\
33 & 379 & 358 & 41.2 & 8.7 & 7.98 \\
49 & 438 & 331 & 40.5 & 8.2 & 7.63 \\
80 & 470 & 309 & 41.6 & 7.4 & 7.38 \\
122 & 485 & 299 & 41.3 & 7.2 & 7.49 \\
\hline
\end{tabular}

a Measured on water extracts of compost samples.

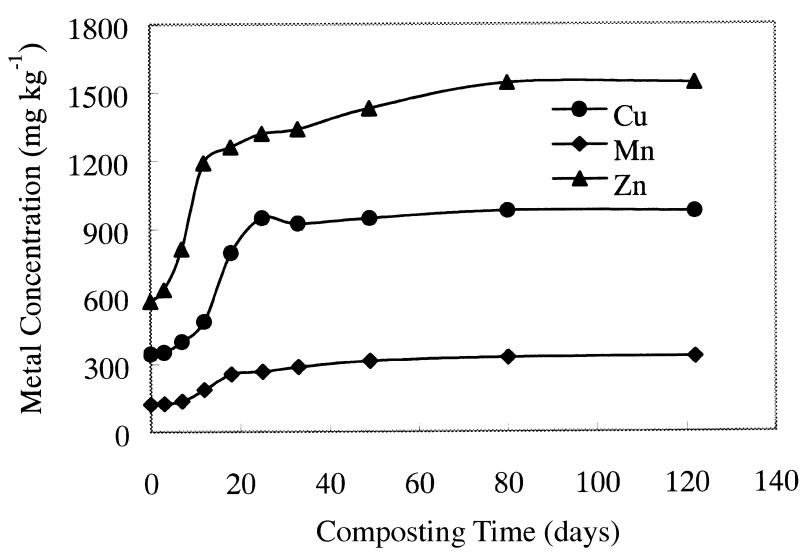

Fig. 2. Total concentrations of $\mathrm{Cu}, \mathrm{Mn}$, and $\mathrm{Zn}$ in separated swine manure during the composting process.

during composting. Major changes in the metal concentrations in SSM composts were recorded during the first 25 days of the process, paralleling the OM decomposition.

\subsection{Water-soluble fractions of organics and metals}

Water-soluble fractions of organics and metals are the most readily bioavailable in composts applied to soils (Leita and De Nobili, 1991).

\subsubsection{Water-soluble organic $C$}

The water extract exhibited a slightly alkaline $\mathrm{pH}$ throughout the composting process (Table 1). The water-soluble organic $\mathrm{C}$ level rapidly increased to a maximum at Day 18 and declined thereafter (Fig. 3). As C compounds that are highly available (e.g. sugars, hemicellulose, organic and amino acids, and proteins) to microbes were degraded during the rapid decomposition phase, metabolic products were continuously released, resulting in an increase in water-soluble organic $\mathrm{C}$. After the rapid decomposition phase, the substrate level was low and resulted in a reduction in soluble C. Water-

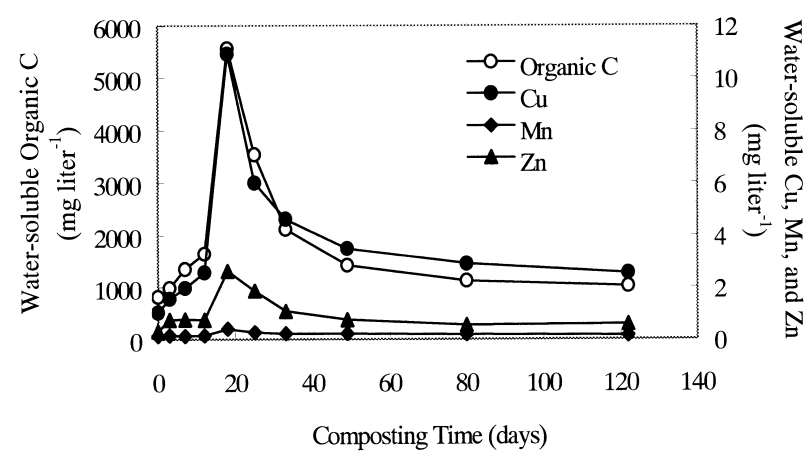

Fig. 3. Water-soluble organic $\mathrm{C}, \mathrm{Cu}, \mathrm{Mn}$, and $\mathrm{Zn}$ concentrations during separated swine manure composting.

soluble fractions of organic $\mathrm{C}$ were small in the raw material $(2 \%$, expressed as percent of total compost organic C) and final compost (4\%) but were substantial at the end of the rapid decomposition phase (up to $17.5 \%$ ). Iannotti et al. (1994) found a similar watersoluble organic $\mathrm{C}$ trend for composting of MSW. Leita and De Nobili (1991) and Inbar et al. (1993), however, reported that water-soluble organic $\mathrm{C}$ declined throughout the composting process for MSW and cattle manure. These results suggest that the type of raw material and composting pattern are of major importance to the dissolution of organic $\mathrm{C}$ during composting.

\subsubsection{Water-soluble fractions of metals}

The increase in total concentrations during composting was not accompanied by a corresponding increase in the amount of water-soluble $\mathrm{Cu}, \mathrm{Mn}$, and $\mathrm{Zn}$. Temporal changes in the water-soluble fractions of $\mathrm{Cu}, \mathrm{Mn}$, and $\mathrm{Zn}$ were reflected by changes in water-soluble organic $\mathrm{C}$ concentrations, which increased to a maximum at Day 18 and then declined (Fig. 3).

The water-soluble fraction of $\mathrm{Cu}$ (expressed as percent of the total concentration in the sample) increased from $3 \%$ in the raw SSM to $5 \%$ at Day 12, sharply increased to about $16 \%$ at Day 18 , and gradually decreased to $3 \%$ in the mature compost. The waterextractable fractions of $\mathrm{Mn}$ or $\mathrm{Zn}$ increased from $1 \%$ in the raw material to $2 \%$ at Day 18 and then gradually decreased to $0.5 \%$ at the end of the process. This result indicates that composting substantially modifies $\mathrm{Cu}$ leachability in SSM compost and appears to have little influence on $\mathrm{Mn}$ or $\mathrm{Zn}$ leachability. The concentrations of $\mathrm{Cu}, \mathrm{Mn}$, or $\mathrm{Zn}$ in the water extracts during composting were highly correlated to water-soluble organic C concentrations with correlation coefficients of 0.98 , 0.94, and 0.99, respectively. Dudley et al. (1986) found a similar trend for sludge-amended soils. Leita and De Nobili (1991) also found a similar $\mathrm{Cu}$ trend for MSW, but the solubility of $\mathrm{Zn}$ declined. Tiquia et al. (1997) found that the amounts of water-extractable $\mathrm{Cu}$ or $\mathrm{Zn}$ declined throughout the process during composting of 
spent pig manure. The water-extractable fraction with $\mathrm{Cu}$ greater than $\mathrm{Zn}$ in SSM composts was similar to previous results reported for MSW sewage sludge cocompost or a mature MSW compost (Sims and Kline, 1991; Tisdell and Breslin, 1995).

\subsection{Sequential extraction}

\subsubsection{Carbon distribution}

The percentages of compost $\mathrm{C}$ extracted by sequential extraction with $\mathrm{H}_{2} \mathrm{O}, \mathrm{KCl}, \mathrm{Na}_{4} \mathrm{P}_{2} \mathrm{O}_{7}, \mathrm{NaOH}$, and $\mathrm{HNO}_{3}$ (one single extraction with each reagent) increased from $49 \%$ and leveled off at $60 \%$ of total compost $C$ by Day 18 (Table 2). Water soluble fractions of organic $\mathrm{C}$ were small in the raw material $(2 \%)$ and mature compost $(4 \%)$ but were substantial at the end of the rapid decomposition phase (up to $17.5 \%$; Table 2). The amount of $\mathrm{KCl}$-extracted organic $\mathrm{C}$ was relatively small $(1-3 \%)$ but showed a similar trend as that of the water extracts. Either $\mathrm{Na}_{4} \mathrm{P}_{2} \mathrm{O}_{7}$ or $\mathrm{NaOH}$ - extracted organic levels increased from 4 or $14 \%$, respectively, in the raw material to $21 \%$ in the mature compost, whereas $\mathrm{HNO}_{3}$ extracted organic $\mathrm{C}$ decreased from 28 to $12 \%$. Although organic $\mathrm{C}$ might have carried over from the water to the $\mathrm{KCl}$ extract and from the $\mathrm{KCl}$ to the $\mathrm{Na}_{4} \mathrm{P}_{2} \mathrm{O}_{7}$ extract, the magnitude should be small. Carryover to the $\mathrm{NaOH}$ and $\mathrm{HNO}_{3}$ extracts was eliminated by washing with water before changing extractants.

\subsubsection{Humification of $O M$}

Organic matter extracted with either $\mathrm{Na}_{4} \mathrm{P}_{2} \mathrm{O}_{7}$ or $\mathrm{NaOH}$ is traditionally considered to be a humic substance (HS). In this study, the total level of HS increased during the composting process from $18.2 \%$ of total compost $\mathrm{C}$ in the raw material to $42.4 \%$ in the final compost (Table 3). Tiquia et al. (1997) found that total levels of HS increase from $10 \%$ of OM in the raw material to $16 \%$ of $\mathrm{OM}$ in the final compost during spent pig litter composting. Chefetz et al. (1996) reported that $18 \%$ of organic matter was in the extracted humic form measured by repeated extraction (eight times) with $\mathrm{NaOH}$ throughout the MSW composting process. These results indicate a higher degree of humification of organic matter in SSM composts than in spent pig litter and MSW composts.

The levels of HA and FA in SSM compost at various stages of the process represent the humification process (Table 3). In general, fresh composts contain low levels of HA and higher levels of FA (Saviozzi et al., 1988; Chefetz et al., 1996), a trend also shown in this study. Of the humic substances extracted with $\mathrm{Na}_{4} \mathrm{P}_{2} \mathrm{O}_{7}$ and $\mathrm{NaOH}$, HA percentages increased, and FA levels decreased with time. The increasing level of HA represents the degree of humification and maturity of the compost. The HA/FA ratio is used commonly to determine compost stability and maturity. The $\mathrm{HA} / \mathrm{FA}$ ratio of $\mathrm{Na}_{4} \mathrm{P}_{2} \mathrm{O}_{7}$ extracts increased from 0.54 to 3.55 and that of $\mathrm{NaOH}$ increased from 0.28 to 1.08 . A combined $\mathrm{HA} / \mathrm{FA}$ ratio (i.e. weighted average of $\mathrm{HA} / \mathrm{FA}$ ratios in $\mathrm{Na}_{4} \mathrm{P}_{2} \mathrm{O}_{7}$ and $\mathrm{NaOH}$ extracts) may be more meaningful than an individual ratio for either $\mathrm{Na}_{4} \mathrm{P}_{2} \mathrm{O}_{7}$ or $\mathrm{NaOH}$ extract as an index of maturity. The weighted HA/FA ratio increased from 0.33 in the raw material to 1.85 in the mature compost.

Thus, parameters such as ash content, $\mathrm{C} / \mathrm{N}$ ratio, metal concentrations, extracted humic $\mathrm{C}$, and the combined HA/FA ratio can be used as maturity indices. Linear correlation analysis (Table 4$)$ reveals that all of these parameters were significantly $(P \leqslant 0.01)$ correlated to each other and all were good indicators of SSM compost maturity.

\subsubsection{Distribution of metals}

Metals in the water-soluble fraction may be readily leachable and bioavailable in the environment. Metals in the exchangeable and organically complexed fractions are relatively labile and may be potentially bioavailable, and metals in the organically bound and solid

Table 2

Distribution of compost $\mathrm{C}$ in the various fractions as a percentage of total compost $\mathrm{C}$ during composting

\begin{tabular}{|c|c|c|c|c|c|c|c|}
\hline \multirow{2}{*}{$\begin{array}{l}\text { Composting } \\
\text { time (days) }\end{array}$} & \multicolumn{6}{|c|}{ Extractable organic C } & \multirow[t]{2}{*}{ Residue $^{\mathrm{a}}$} \\
\hline & $\mathrm{H}_{2} \mathrm{O}$ & $\mathrm{KCl}$ & $\mathrm{Na}_{4} \mathrm{P}_{2} \mathrm{O}_{7}$ & $\mathrm{NaOH}$ & $\mathrm{HNO}_{3}$ & Total & \\
\hline 0 & 2.1 & 0.8 & 4.1 & 14.1 & 28.0 & 49.1 & 50.9 \\
\hline 3 & 2.6 & 0.9 & 4.5 & 14.9 & 28.0 & 50.9 & 49.1 \\
\hline 7 & 3.6 & 1.0 & 4.9 & 15.4 & 27.4 & 52.3 & 47.7 \\
\hline 12 & 4.6 & 1.1 & 6.9 & 16.3 & 26.6 & 55.5 & 44.5 \\
\hline 18 & 17.5 & 2.8 & 11.9 & 14.3 & 13.8 & 60.3 & 39.7 \\
\hline 25 & 11.9 & 2.1 & 12.7 & 15.6 & 16.4 & 58.7 & 41.3 \\
\hline 33 & 7.7 & 1.6 & 16.1 & 19.7 & 15.6 & 60.7 & 39.3 \\
\hline 49 & 5.5 & 1.5 & 19.4 & 21.5 & 13.6 & 61.5 & 38.5 \\
\hline 80 & 4.4 & 1.2 & 19.4 & 20.8 & 14.9 & 60.7 & 39.3 \\
\hline 122 & 4.0 & 1.1 & 21.0 & 21.4 & 12.4 & 59.9 & 40.1 \\
\hline
\end{tabular}

a Calculated by subtraction of total extracted organic $\mathrm{C}$ from compost $\mathrm{C}$. 
Table 3

Extracted humic $\mathrm{C}$ and its distribution in fulvic acid (FA) and humic acid (HA) fractions during separated swine manure composting

\begin{tabular}{|c|c|c|c|c|c|c|c|c|}
\hline \multirow{2}{*}{$\begin{array}{l}\text { Composting } \\
\text { time (days) }\end{array}$} & \multirow{2}{*}{$\begin{array}{l}\text { Extracted } \\
\text { humic } C^{\text {a }}(\%)\end{array}$} & \multicolumn{3}{|c|}{$\mathrm{Na}_{4} \mathrm{P}_{2} \mathrm{O}_{7}$ extract } & \multicolumn{3}{|c|}{$\mathrm{NaOH}$ extract } & \multirow{2}{*}{$\begin{array}{l}\text { Combined } \\
\text { HA/FA }\end{array}$} \\
\hline & & FA $(\%)$ & $\mathrm{HA}^{\mathrm{b}}(\%)$ & $\mathrm{HA} / \mathrm{FA}$ & FA $(\%)$ & $\mathrm{HA}^{\mathrm{b}}(\%)$ & HA/FA & \\
\hline 0 & 18.2 & 65 & 35 & 0.54 & 78 & 22 & 0.28 & 0.33 \\
\hline 3 & 19.4 & 57 & 43 & 0.75 & 79 & 21 & 0.27 & 0.35 \\
\hline 7 & 20.3 & 52 & 48 & 0.92 & 78 & 22 & 0.28 & 0.39 \\
\hline 12 & 23.2 & 44 & 56 & 1.27 & 76 & 24 & 0.32 & 0.50 \\
\hline 18 & 26.2 & 35 & 65 & 1.86 & 61 & 39 & 0.64 & 1.03 \\
\hline 25 & 28.3 & 32 & 68 & 2.13 & 64 & 36 & 0.56 & 1.01 \\
\hline 33 & 35.8 & 29 & 71 & 2.45 & 58 & 42 & 0.72 & 1.22 \\
\hline 49 & 40.9 & 24 & 76 & 3.17 & 57 & 43 & 0.75 & 1.42 \\
\hline 80 & 40.2 & 24 & 76 & 3.17 & 51 & 49 & 0.96 & 1.63 \\
\hline 122 & 42.4 & 22 & 78 & 3.55 & 48 & 52 & 1.08 & 1.85 \\
\hline
\end{tabular}

a Sum of $\mathrm{C}$ extracted by $\mathrm{Na}_{4} \mathrm{P}_{2} \mathrm{O}_{7}$ and $\mathrm{NaOH}$ (as shown in Table 2) as a percentage of total compost $\mathrm{C}$.

b Calculated by the difference between extract and FA values.

${ }^{c}$ Weighted average of $\mathrm{HA} / \mathrm{FA}$ ratios in $\mathrm{Na}_{4} \mathrm{P}_{2} \mathrm{O}_{7}$ and $\mathrm{NaOH}$ extracts.

Table 4

Correlation coefficients $(r)$ between parameters used for separated swine manure compost maturity indices

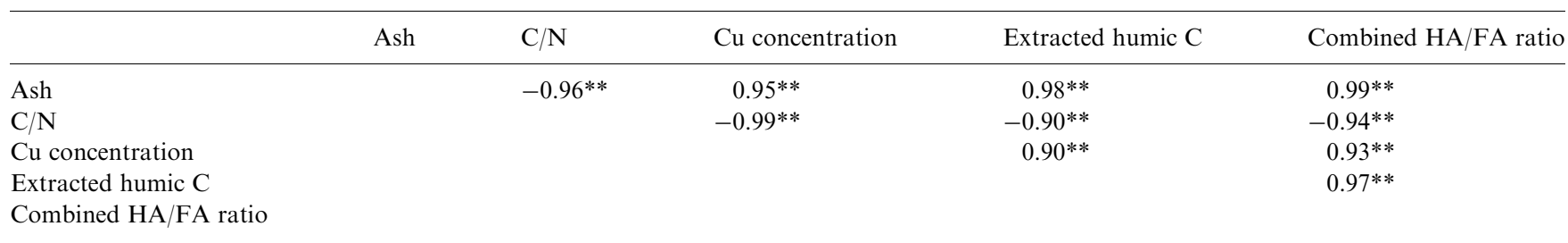

**Significance at the $P \leqslant 0.01$ level $(n=10)$.

particulate fractions are relatively immobile and may not be readily bioavailable. However, metals in the residual fraction are tightly bound and not expected to be released readily under natural conditions (He et al., 1995). The differences in the distribution patterns of $\mathrm{Cu}$, $\mathrm{Mn}$, and $\mathrm{Zn}$ in the SSM composts studied indicate that the potential mobility and bioavailability of these elements vary in the environment.

Results show that the distribution of $\mathrm{Cu}, \mathrm{Mn}$, and $\mathrm{Zn}$ in various fractions (water-soluble fraction excluded) were generally independent of composting age and of total metal concentrations (Fig. 4). The water-soluble fractions of $\mathrm{Mn}$ and $\mathrm{Zn}$ were both $<2 \%$ throughout the process and may be the most mobile and bioavailable fractions of the metals. The water-soluble fractions of $\mathrm{Cu}$ increased from $3 \%$ in the raw SSM to about $16 \%$ at Day 18 , then decreased to $3 \%$ in the final compost. The exchangeable fractions of $\mathrm{Cu}, \mathrm{Mn}$, and $\mathrm{Zn}$ during the composting process were low, $<4,2$, and $1 \%$, respectively. In general, only a small portion of total compost $\mathrm{Cu}, \mathrm{Mn}$, and $\mathrm{Zn}(<5,13$, and $3 \%$, respectively) remained in the final residue.

In the 10 composts at various stages of composting, the greatest amount of $\mathrm{Cu}$ was in the organically bound fraction, followed by the organically complexed, solid particulate, and water soluble fractions, with the smallest amounts of $\mathrm{Cu}$ being associated with the exchangeable and residual fractions (Fig. 4). Approximately $70 \%$ of total $\mathrm{Cu}$ in these composts was associated with the organically bound and organically complexed fractions, which may have been due to a high affinity of $\mathrm{Cu}$ for organics (Stumm and Morgan, 1981). Though, there were some small changes in $\mathrm{Cu}$ distribution observed during the process; the organically complexed fractions tended to decrease, the organically bound fractions increased, and the water-soluble fractions increased to a maximum at Day 18 and then declined thereafter. Statistical analysis reveals that organically complexed or organically bound fraction of $\mathrm{Cu}$ was significantly correlated to ash, organic $\mathrm{C}$, extracted humic $\mathrm{C}, \mathrm{HA} / \mathrm{FA}$, and total $\mathrm{Cu}$ concentrations during the process $(P \leqslant 0.05$; Table 5).

At various stages of composting, the highest amounts of $\mathrm{Mn}$ were present in the solid particulate and organically complexed fractions, followed by the residual, organically bound, exchangeable, and water-soluble fractions (Fig. 4). In the mature compost, $47 \%$ of $\mathrm{Mn}$ was present in the solid particulate fraction, $39 \%$ with the organically complexed fraction, $8 \%$ with the residual fraction, $4 \%$ with the organically bound fraction, and $1 \%$ each with the exchangeable and water-soluble fractions. However, due to low total Mn content of the 
(a)

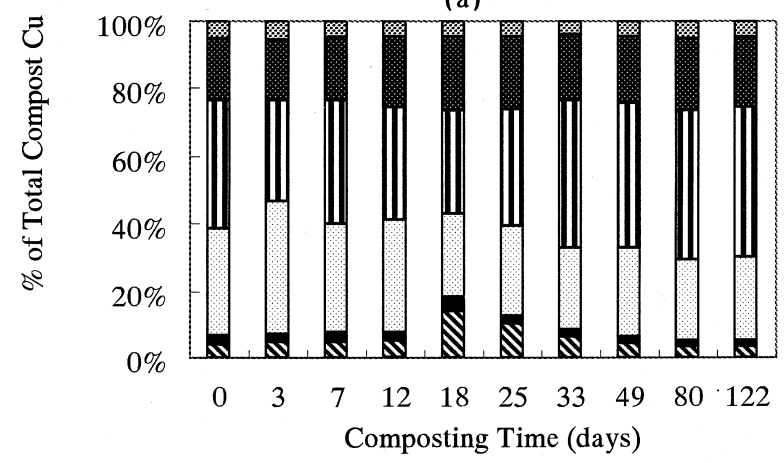

(b)

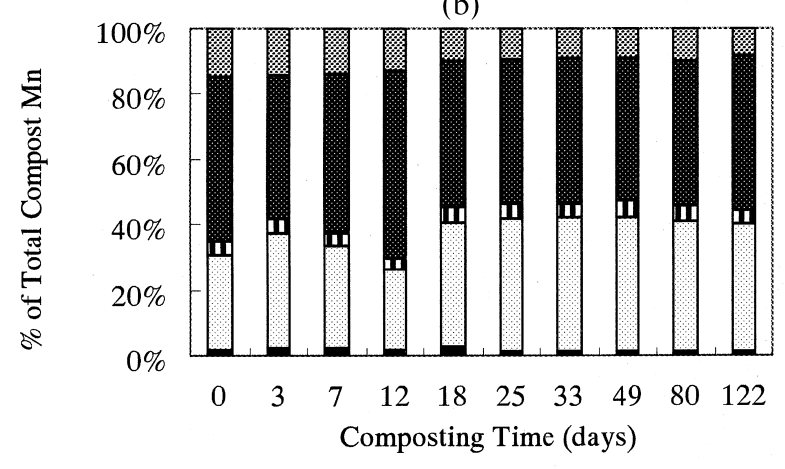

(c)

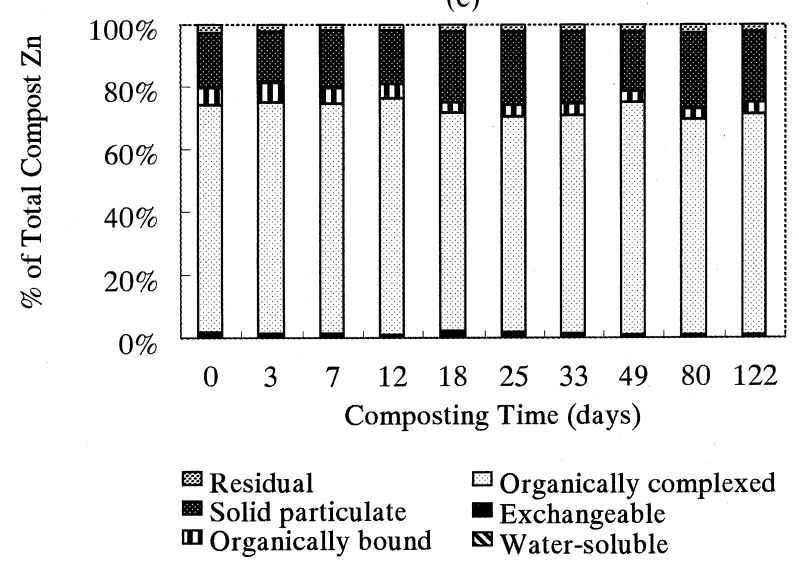

Fig. 4. Distribution of (a) $\mathrm{Cu}$, (b) $\mathrm{Mn}$, and (c) $\mathrm{Zn}$ in the various fractions by sequential extraction.

final SSM compost (331 $\mathrm{mg} \mathrm{kg}^{-1}$ ) compared with soil Mn content of $1000-3000 \mathrm{mg} \mathrm{kg}^{-1}$ (Alloway, 1995), it is unlikely that application of SSM composts to soils will cause Mn toxicity to plants. In fact, Chaney and Ryan (1993) are concerned that application of alkaline biosolids can result in Mn deficiency in susceptible crops. Organically complexed or organically bound fraction was significantly correlated to ash, organic $\mathrm{C}, \mathrm{C} / \mathrm{N}$, extracted humic $\mathrm{C}, \mathrm{HA} / \mathrm{FA}$, and total $\mathrm{Cu}$ concentrations $(P \leqslant 0.05$; Table 5$)$, while the residual fraction was strongly correlated to these parameters $(P \leqslant 0.01)$.

At various stages of composting, the major and approximately the same amounts $(71 \%)$ of $\mathrm{Zn}$ were in the organically complexed fraction, with moderate amounts occurring in the solid particulate fraction, a small amount being associated with the organically bound and residual fractions, and the lowest with the water-soluble and exchangeable fractions. Approximately $70 \%$ of total compost $\mathrm{Zn}$ was in the organically complexed fraction, indicating its potential environmental mobility. Exchangeable, organically bound, or solid particulate fraction was significantly correlated to ash, organic $\mathrm{C}, \mathrm{C} / \mathrm{N}$, extracted humic $\mathrm{C}, \mathrm{HA} / \mathrm{FA}$, and total $\mathrm{Cu}$ concentrations during the process $(P \leqslant 0.05$; Table 5).

The distribution of these elements in the various fractions by sequential extraction during composting reveals that the readily leachable fraction (water-soluble fraction) of elements (\% of total compost metals) in SSM compost decreased in the order $\mathrm{Cu}>\mathrm{Mn} \approx \mathrm{Zn}$, whereas the potential mobility of these elements was generally in the order $\mathrm{Zn}>\mathrm{Cu}>\mathrm{Mn}$. Our results were consistent with those of Miller et al. (1986) and L'Herroux et al. (1997), who found a similar pattern of $\mathrm{Cu}$ and $\mathrm{Zn}$ in the solid fraction of raw pig slurry. He et al. (1995) also found a similar Mn and $\mathrm{Zn}$ trend for MSW composts, but most of the $\mathrm{Cu}$ was present in the solid particulate fraction. Tisdell and Breslin (1995) found that $\mathrm{Cu}$ in MSW composts was concentrated in the organic fraction.

\subsubsection{Distribution of metals in fulvic acid and humic acid fractions}

Humic substances have a relatively high capacity to complex with trace metals (Stevenson, 1982). Humic fractions (HA and FA) may differ in complexing trace metals as well as in affinity toward individual metal ions (Stevenson, 1982). It is generally believed that HA represents more stable and condensed forms of humic substances than FA (Stevenson, 1982). Some nonhumic substances, such as low molecular weight polysaccharides, amino acids, and phenolic acids, are recovered as FA based on the operational definition of FA (He et al., 1995). Therefore, relative distributions of trace metals in HA and FA may be used to predict the stability or mobility of trace metals in the environment after SSM compost application.

Most $\mathrm{Cu}, \mathrm{Mn}$, and $\mathrm{Zn}$ were recovered in FA from either $\mathrm{Na}_{4} \mathrm{P}_{2} \mathrm{O}_{7}$ or $\mathrm{NaOH}$ extracts throughout the composting process (Table 6). As high as $99-100 \%$ of $\mathrm{Cu}$ in either $\mathrm{Na}_{4} \mathrm{P}_{2} \mathrm{O}_{7}$ or $\mathrm{NaOH}$ extracts and $\mathrm{Mn}$ in $\mathrm{Na}_{4} \mathrm{P}_{2} \mathrm{O}_{7}$ extracts from raw SSM were retained in the FA fraction and as composting proceeded, the percentage decreased to $72-77 \%$ in the mature compost. This result suggests that although $\mathrm{Cu}$ and $\mathrm{Mn}$ associated with organic components in SSM are less stable during the composting process, they tend to be more stable with composting age. The distribution of $\mathrm{Mn}$ in the $\mathrm{NaOH}$ extract and $\mathrm{Zn}$ in either $\mathrm{Na}_{4} \mathrm{P}_{2} \mathrm{O}_{7}$ or $\mathrm{NaOH}$ extracts in FA and HA remained constant during composting. Therefore, 
Table 5

Matrix correlation (coefficient of correlation $r$ ) of $\mathrm{Cu}, \mathrm{Mn}$, and $\mathrm{Zn}$ extractions with composting parameters

\begin{tabular}{|c|c|c|c|c|c|c|c|}
\hline & $\mathrm{pH}$ & Ash & Organic $\mathrm{C}$ & $\mathrm{C} / \mathrm{N}$ & Extracted humic $\mathrm{C}$ & humic acid/fulvic acid & Total metal ${ }^{a}$ \\
\hline $\mathrm{Cu}$ & & & & & & & $\mathrm{Cu}$ \\
\hline Water-soluble & 0.15 & -0.03 & 0.05 & -0.23 & -0.19 & -0.05 & 0.20 \\
\hline Exchangeable & 0.05 & -0.57 & $0.60^{*}$ & 0.38 & $-0.68^{*}$ & -0.54 & -0.42 \\
\hline Organically complexed & 0.09 & $-0.83^{*}$ & $0.83^{*}$ & $0.90 * *$ & $-0.77^{*}$ & $-0.83^{*}$ & $-0.89^{*}$ \\
\hline Organically bound & -0.18 & $0.73 *$ & $-0.75^{*}$ & -0.59 & $0.81^{*}$ & $0.72^{*}$ & $0.60^{*}$ \\
\hline Solid particulate & 0.07 & 0.54 & -0.55 & $-0.68^{*}$ & 0.46 & 0.58 & $0.68^{*}$ \\
\hline Residual & -0.16 & -0.35 & 0.35 & 0.52 & -0.30 & -0.30 & -0.50 \\
\hline$M n$ & & & & & & & $\mathrm{Mn}$ \\
\hline Water-soluble & -0.05 & -0.57 & $0.60^{*}$ & 0.39 & $-0.67^{*}$ & -0.55 & -0.47 \\
\hline Exchangeable & -0.44 & -0.58 & $0.61^{*}$ & $0.65^{*}$ & -0.58 & -0.54 & $-0.67 *$ \\
\hline Organically complexed & -0.16 & $0.80^{*}$ & $-0.78^{*}$ & $-0.84^{*}$ & $0.72 *$ & $0.75^{*}$ & $0.76^{*}$ \\
\hline Organically bound & -0.42 & $0.70^{*}$ & $-0.70^{*}$ & $-0.71^{*}$ & $0.65^{*}$ & $0.66^{*}$ & $0.65^{*}$ \\
\hline Solid particulate & 0.24 & -0.51 & 0.49 & 0.55 & -0.42 & -0.46 & -0.44 \\
\hline Residual & 0.08 & $-0.95 * *$ & $0.94 * *$ & $0.99 * *$ & $-0.89^{*}$ & $-0.93^{* *}$ & $-0.97 * *$ \\
\hline $\mathrm{Zn}$ & & & & & & & $\mathrm{Zn}$ \\
\hline Water-soluble & 0.24 & -0.27 & 0.28 & 0.01 & -0.40 & -0.25 & -0.15 \\
\hline Exchangeable & 0.08 & $-0.88^{*}$ & $0.89^{*}$ & $0.82^{*}$ & $-0.90 * *$ & $-0.85^{*}$ & $-0.94 * *$ \\
\hline Organically complexed & -0.20 & -0.54 & 0.54 & $0.66^{*}$ & -0.41 & -0.57 & -0.51 \\
\hline Organically bound & 0.17 & $-0.85^{*}$ & $0.85^{*}$ & $0.93 * *$ & $-0.78^{*}$ & $-0.83^{*}$ & $-0.89^{*}$ \\
\hline Solid particulate & 0.06 & $0.78^{*}$ & $-0.78^{*}$ & $-0.87^{*}$ & $0.68^{*}$ & $0.78^{*}$ & $0.78^{*}$ \\
\hline Residual & -0.01 & -0.12 & 0.10 & 0.17 & -0.11 & -0.06 & -0.32 \\
\hline
\end{tabular}

a Total metal: digestion with $\mathrm{HNO}_{3}+\mathrm{HClO}_{4}$.

* Significance at the $P \leqslant 0.05$ level $(n=10)$.

**Significance at the $P \leqslant 0.01$ level $(n=10)$.

Table 6

Distribution of $\mathrm{Cu}, \mathrm{Mn}$, and $\mathrm{Zn}$ in fulvic acid (FA) and humic acid (HA) fractions of $\mathrm{Na}_{4} \mathrm{P}_{2} \mathrm{O}_{7}$ and $\mathrm{NaOH}$ extracts during the composting process

\begin{tabular}{|c|c|c|c|c|c|c|c|c|c|c|c|c|}
\hline \multirow[t]{3}{*}{ Composting time (days) } & \multicolumn{4}{|l|}{$\mathrm{Cu}$} & \multicolumn{4}{|l|}{$\mathrm{Mn}$} & \multicolumn{4}{|l|}{$\mathrm{Zn}$} \\
\hline & \multicolumn{2}{|c|}{$\mathrm{Na}_{4} \mathrm{P}_{2} \mathrm{O}_{7}$} & \multicolumn{2}{|c|}{$\mathrm{NaOH}$} & \multicolumn{2}{|c|}{$\mathrm{Na}_{4} \mathrm{P}_{2} \mathrm{O}_{7}$} & \multicolumn{2}{|c|}{$\mathrm{NaOH}$} & \multicolumn{2}{|c|}{$\mathrm{Na}_{4} \mathrm{P}_{2} \mathrm{O}_{7}$} & \multicolumn{2}{|c|}{$\mathrm{NaOH}$} \\
\hline & FA & $\mathrm{HA}^{\mathrm{a}}$ & FA & $\mathrm{HA}^{\mathrm{a}}$ & FA & $\mathrm{HA}^{\mathrm{a}}$ & FA & $\mathrm{HA}^{\mathrm{a}}$ & FA & $\mathrm{HA}^{\mathrm{a}}$ & FA & $\mathrm{HA}^{\mathrm{a}}$ \\
\hline 0 & 99 & 1 & 100 & 0 & 100 & 0 & 89 & 11 & 99 & 1 & 100 & 0 \\
\hline 3 & 99 & 1 & 100 & 0 & 100 & 0 & 83 & 17 & 100 & 0 & 100 & 0 \\
\hline 7 & 97 & 3 & 99 & 1 & 97 & 3 & 86 & 14 & 99 & 1 & 99 & 1 \\
\hline 12 & 92 & 8 & 95 & 5 & 92 & 8 & 86 & 14 & 97 & 3 & 100 & 0 \\
\hline 18 & 86 & 14 & 96 & 4 & 89 & 11 & 98 & 2 & 98 & 2 & 100 & 0 \\
\hline 25 & 85 & 15 & 89 & 11 & 83 & 17 & 94 & 6 & 100 & 0 & 100 & 0 \\
\hline 33 & 84 & 16 & 82 & 18 & 87 & 13 & 99 & 1 & 96 & 4 & 100 & 0 \\
\hline 49 & 81 & 19 & 83 & 17 & 85 & 15 & 98 & 2 & 91 & 9 & 99 & 1 \\
\hline 80 & 75 & 25 & 77 & 23 & 82 & 18 & 94 & 6 & 96 & 4 & 100 & 0 \\
\hline 122 & 72 & 28 & 73 & 27 & 77 & 23 & 87 & 13 & 93 & 7 & 100 & 0 \\
\hline
\end{tabular}

a Calculated by subtraction of metals in FA from metals in total extract.

composting age had little influence on $\mathrm{Zn}$ stability with regards to association with organic components in SSM. $\mathrm{He}$ et al. (1995) also found that most of the Mn and $\mathrm{Zn}$ in mature MSW compost was recovered in FA fractions, but more $\mathrm{Cu}$ was retained in HA than in FA fractions.

\section{Conclusions}

This article demonstrates that metal concentrations as well as ash content, $\mathrm{C} / \mathrm{N}$ ratio, extracted humic $\mathrm{C}$, and weighted HA/FA ratio were each good indicators of SSM compost stability and maturity. All of these parameters reveals that the SSM compost, described in this study, was mature and stable after about 80 days of composting. Although $\mathrm{Cu}, \mathrm{Mn}$, and $\mathrm{Zn}$ concentrations increased approximately 2.7 -fold in the final compost, the results of this study show that the leachability of these elements in final compost is likely low. However, enhanced leaching of $\mathrm{Cu}$ (up to $16 \%$ of total compost $\mathrm{Cu})$ at the end of rapid decomposition phase due to substantial dissolution of organic $\mathrm{C}(17.5 \%$ of total compost 
C) indicates that application of immature SSM compost on soil may not be a risk-free management practice. Composting age and metal concentration appear to have little influence on water-soluble fractions of $\mathrm{Mn}$ and $\mathrm{Zn}$ and the distribution of $\mathrm{Cu}, \mathrm{Mn}$, and $\mathrm{Zn}$ among the different extractable forms. Copper was primarily in the organically bound fractions during the composting process. Manganese was mainly associated with the solid particulate fractions. Zinc was concentrated in the organically complexed fractions. The distribution of the three metals in the various fractions indicates their differences in potential leachability and bioavailability. Of the elements studied, $\mathrm{Zn}$ in SSM compost appeared to be the most potentially leachable and bioavailable.

\section{References}

Alloway, B.J., 1995. Heavy Metals in Soils, 2nd Edition. Blackie Academic \& Professional, London.

Chaney, R.L., Ryan, J.A., 1993. Heavy metals and toxic organic pollutants in MSW-composts: research results on phytoavailability, bioavailability, etc. In: Hoitink, H.A.J., Keener, H.M. (Eds.), Science and Engineering of Composting: Design, Environmental, Microbiological and Utilization aspects. Renaissance Publications, Worthington, Ohio, pp. 451-506.

Chefetz, B., Hatcher, P.G., Hadar, Y., Chen, Y., 1996. Chemical and biological characterization of organic matter during composting of municipal solid waste. Journal of Environmental Quality 25, 776785.

Dudley, L.M., McNeal, B.L., Baham, J.E., 1986. Time-dependent changes in soluble organics, copper, nickel, and zinc from sludge amended soils. Journal of Environmental Quality 15, 188-192.

Giusquiani, P.L., Concezzi, L., Businelli, M., Macchioni, A., 1998. Fate of pig sludge liquid fraction in calcareous soil: agricultural and environmental implications. Journal of Environmental Quality 27, 364-371.

He, X.T., Logan, T.J., Traina, S.J., 1995. Physical and chemical characteristics of selected U. S. municipal solid waste composts. Journal of Environmental Quality 24, 543-552.

Iannotti, D.A., Grebus, M.E., Toth, B.L., Madden, L.V., Hoitink, H.A.J., 1994. Oxygen respirometry to assess stability and maturity of composted municipal solid waste. Journal of Environmental Quality 23, 1177-1183.

Ihnat, M., Fernandes, L., 1996. Trace elemental characterization of composted poultry manure. Bioresource Technology 57, 143-156.

Inbar, Y., Hadar, Y., Chen, Y., 1993. Recycling of cattle manure: the composting process and characterization of maturity. Journal of Environmental Quality 22, 857-863.
Jones, J.B., Case, V.W., 1990. Sampling, handling, and analyzing plant tissue samples. In: Westerman, R.L. (Ed.), Soil Testing and Plant Analysis, 3rd Edition (SSSA Book Series 3). SSSA, Madison, WI, pp. 389-427.

King, L.D., Burns, J.C., Westerman, P.W., 1990. Long-term swine lagoon effluent applications on 'Coastal' bermudagrass: I. Effect on nutrient accumulation in soil. Journal of Environmental Quality 19, 756-760.

Leita, L., De Nobili, M., 1991. Water-soluble fractions of heavy metals during composting of municipal municipal solid waste. Journal of Environmental Quality 20, 73-78.

L'Herroux, L., Le Roux, S., Appriou, P., Martinez, J., 1997. Behaviour of metals following intensive pig slurry applications to a natural field treatment process in Brittany (France). Environmental Pollution 97 (1-2), 119-130.

Miller, W.P., Martens, D.C., Zelazny, L.W., Kornegay, E.T., 1986. Forms of solid phase copper in copper-enriched swine manure. Journal of Environmental Quality 15 (1), 69-72.

Mullins, G.L., Martens, D.C., Miller, W.P., Kornegay, E.T., Hallock, D.L., 1982. Copper availability, form, and mobility in soils from three annual copper-enriched hog manure applications. Journal of Environmental Quality 11 (2), 316-320.

Payne, G.G., Martens, D.C., Kornegay, E.T., Lindemann, M.D., 1988. Availability and form of copper in three soils following eight annual applications of copper-enriched swine manure. Journal of Environmental Quality 17, 740-746.

Petruzzelli, G., Szymura, I., Lubrano, L., Pezzarossa, B., 1989. Chemical speciation of heavy metals in different size fractions of compost from solid urban wastes. Environmental Technology Letter 10, 521-526.

SAS Institute, 1987. Users Guide. SAS Institute, Cary, NC.

Saviozzi, A., Levi-Minzi, R., Riffaldi, R., 1988. Maturity evaluation of organic waste. BioCycle 29, 54-56.

Sims, J.T., Kline, J.S., 1991. Chemical fractionation and plant uptake of heavy metals in soils amended with co-composted sewage sludge. Journal of Environmental Quality 20, 387-395.

Stevenson, F.J., 1982. Humus Chemistry: Genesis, Composition, Reaction. John Wiley, New York

Stumm, W., Morgan, J.J., 1981. Aquatic chemistry: an Introduction Emphasizing Chemical Equilibria in Natural Waters, 2nd Edition. John Wiley, New York.

Tiquia, S.M., Tam, N.F.Y., Hodgkiss, I.J., 1997. Composting of spent pig litter at different seasonal temperatures in subtropical climate. Environmental Pollution 98 (1), 97-104.

Tisdell, S.E., Breslin, V.T., 1995. Characterization and leaching of elements from municipal solid waste compost. Journal of Environmental Quality 24, 827-833.

Wadman, W.P., Sluijsmans, C.M.J., de la Lande Cremer, L.C.N., 1987. Value of animal manures: changes in perception. In: van der Meer, H.G. et al. (Eds.), Animal Manure on Grassland and Fodder Crops. Fertilizer or Waste? Martinus Nijhoff Pub., Dordrecht, The Netherlands, pp. 1-16. 